\title{
A Model for Simulation of Surface-Water Integrated Flow and Transport in Two Dimensions: User's Guide for Application to Coastal Wetlands
}

\author{
By Eric D. Swain
}

Prepared as part of the

U.S. Geological Survey Greater Everglades Priority Ecosystems Science Program and the

National Park Service Critical Ecosystem Studies Initiative

Open-File Report 2005-1033 


\section{U.S. Department of the Interior \\ Gale A. Norton, Secretary}

\section{U.S. Geological Survey Charles G. Groat, Director}

U.S. Geological Survey, Reston, Virginia: 2005

For sale by U.S. Geological Survey, Information Services

Box 25286, Denver Federal Center

Denver, CO 80225

For more information about the USGS and its products:

Telephone: 1-888-ASK-USGS

World Wide Web: http://www.usgs.gov/

Any use of trade, product, or firm names in this publication is for descriptive purposes only and does not imply endorsement by the U.S. Government.

Although this report is in the public domain, permission must be secured from the individual copyright owners to reproduce any copyrighted materials contained within this report.

Suggested citation: Swain, E.D., 2005, A Model for Simulation of Surface-Water Integrated Flow and Transport in Two Dimensions: User's Guide for Application to Coastal Wetlands: U.S. Geological Survey Open-File Report 2005-1033, 88 p. 


\section{Preface}

This report provides documentation for the U.S. Geological Survey (USGS) $\underline{\text { Surface- }}$ Water Integrated $\mathbf{F}$ low and $\mathbf{I}$ ransport in $\underline{\mathbf{T} w 0}$ - $\underline{\mathbf{D}}$ imensions (SWIFT2D) model, for application to coastal wetlands. Some of the material within this report was derived from manuals and technical notes published by the Rand Corporation to describe the original two-dimensional model, referred to as SIM2D, and its supporting simulation system, SIMSYS2D, developed in partnership with the USGS and others. 


\section{Contents}

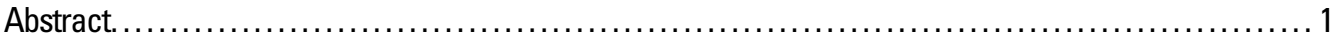

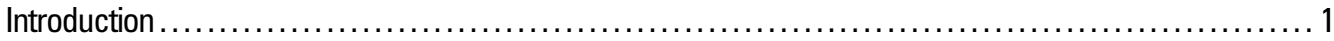

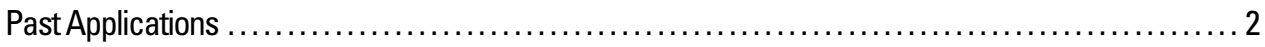

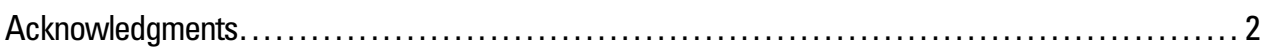

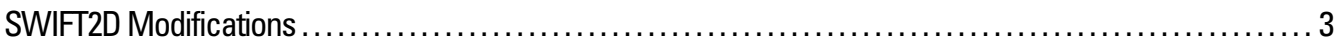

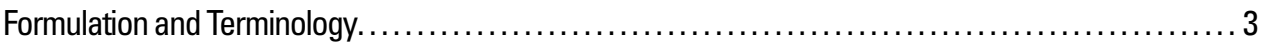

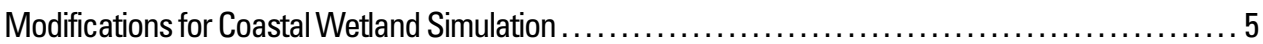

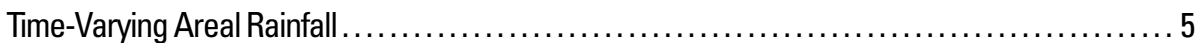

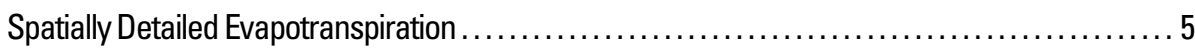

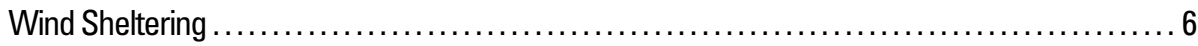

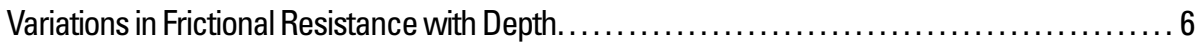

Computational Cells Adjacent to Flow Barriers ................................. 6

Other Code Modifications ................................................. 6

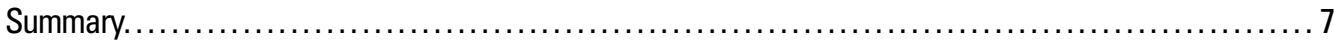

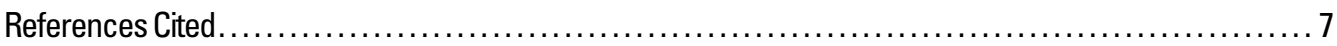

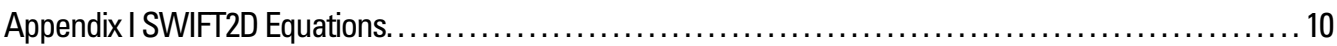

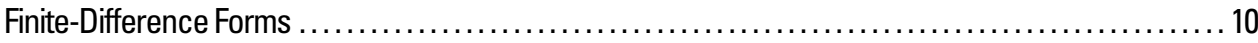

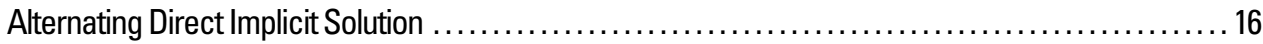

Appendix II.SWIFT2D Program Input with Modifications for Application to Coastal Wetlands . . . . . . . . . 21

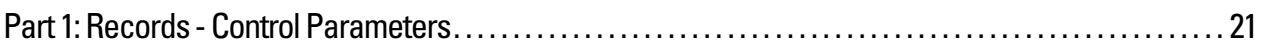

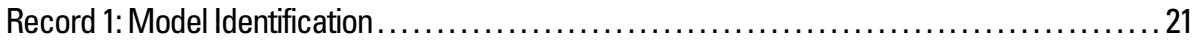

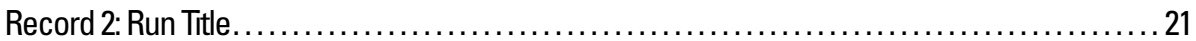

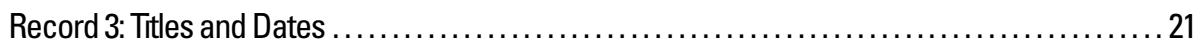

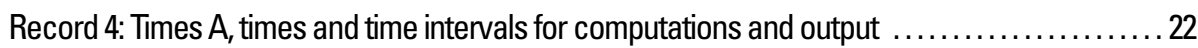

Record 5: Times B, times and time intervals for computations and output $\ldots \ldots \ldots \ldots \ldots \ldots \ldots 25$

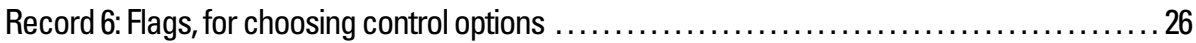

Record 7: Flags, for controlling volume of input values printed $\ldots \ldots \ldots \ldots \ldots \ldots \ldots \ldots \ldots \ldots \ldots \ldots \ldots \ldots \ldots$

Record 8: Flags, for controlling constituent input print volume ....................... 29

Record 9: Flags, for controlling volume of output values printed $\ldots \ldots \ldots \ldots \ldots \ldots \ldots \ldots \ldots \ldots \ldots \ldots \ldots \ldots \ldots \ldots \ldots$

Record 10: Flags, for controlling constituent output print volume ....................... 31

Record 11-14: Print Times, to print selected hydrodynamic and constituent variables .......... 31

Record 15: Data Array Dimension A, grid, constituents, checkpoints, sources ............... 31

Record 16: Data Array Dimension B, barriers, wind, air pressure $\ldots \ldots \ldots \ldots \ldots \ldots \ldots \ldots \ldots \ldots \ldots \ldots \ldots \ldots \ldots$

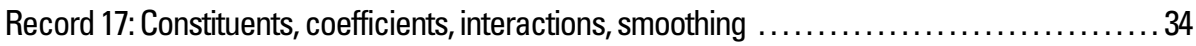

Record 18: Physical Characteristics, cells, water levels, coefficients, smoothing .............. 35

Record 19: Coefficients and Constants A, gravity, densities, coefficients.................... 37

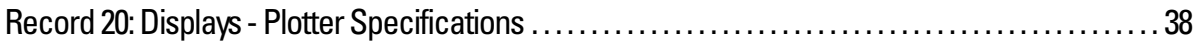

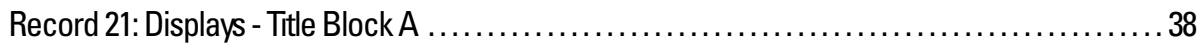

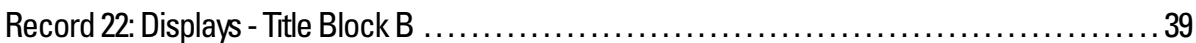

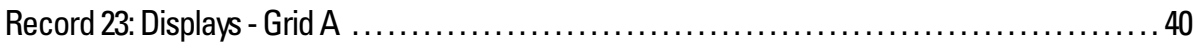

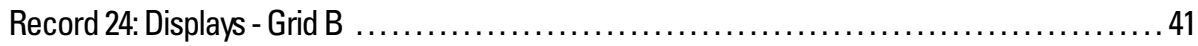

Record 25: Coarse Grid Parameters, ratio of normal grid to coarse grid.................. 42 
Record 26: Coefficients and Constants B, specific gravity, energy coefficients .............. 43

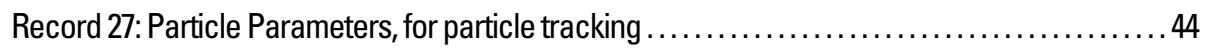

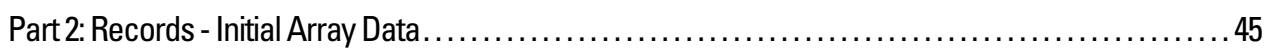

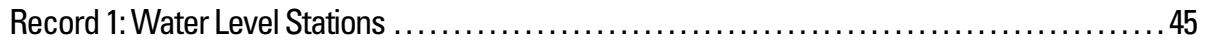

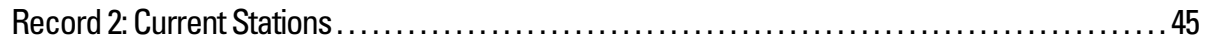

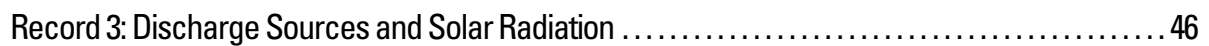

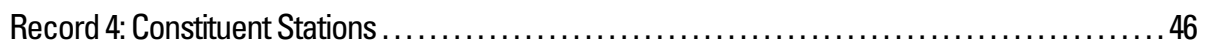

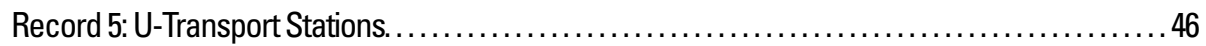

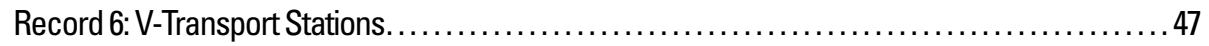

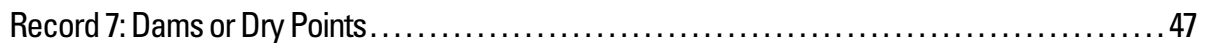

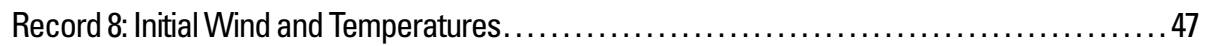

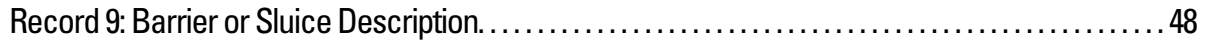

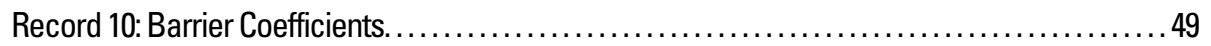

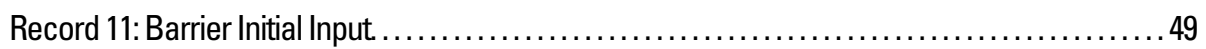

Record 12-19: Tide Openings, locations, initial conditions, Fourier components . ............50-54

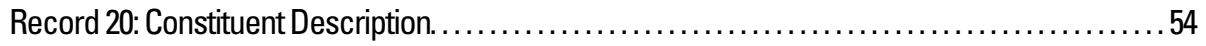

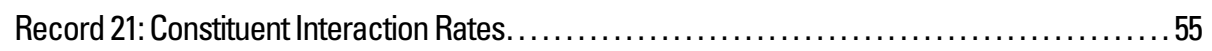

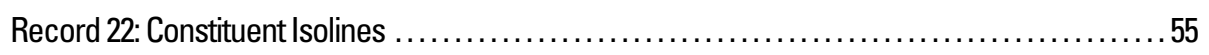

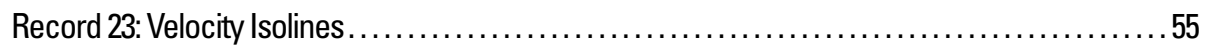

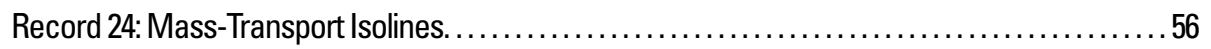

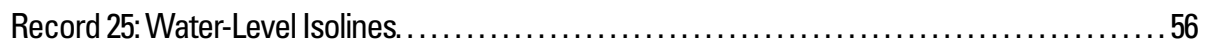

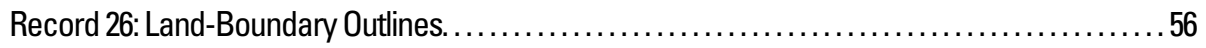

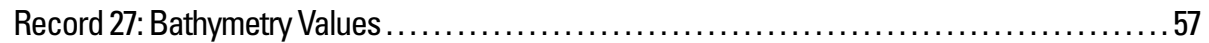

Record 28-35: Coefficient Input, viscosity, diffusion, Manning's, benthic demand. ............58-61

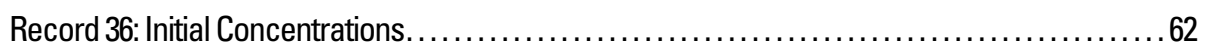

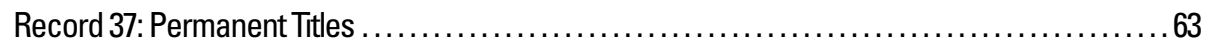

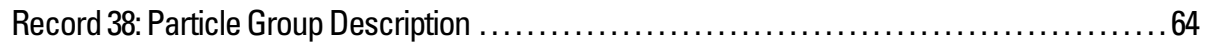

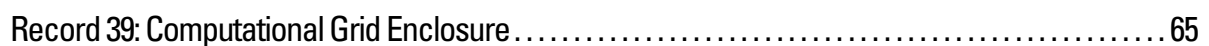

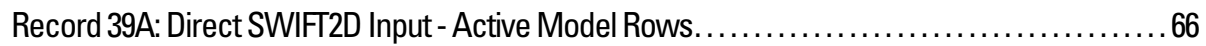

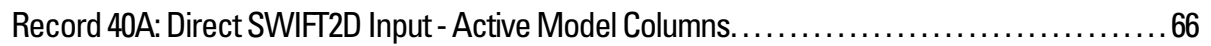

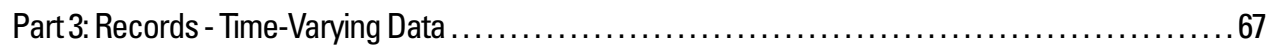

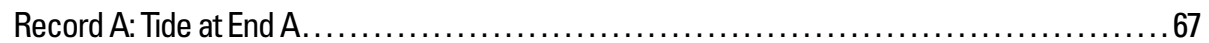

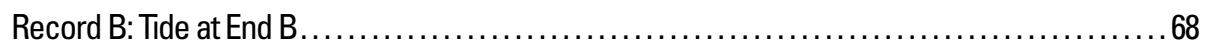

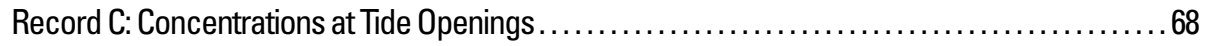

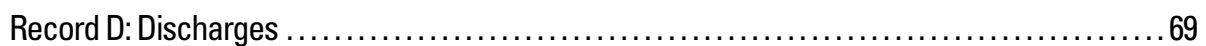

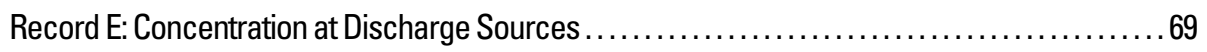

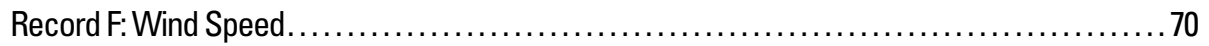

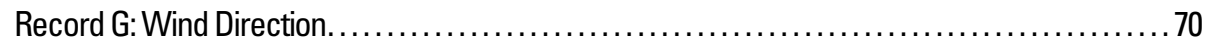

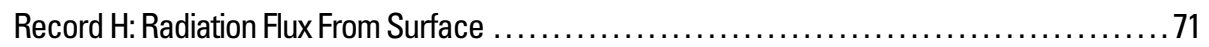

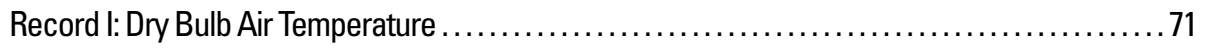

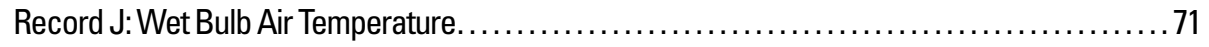

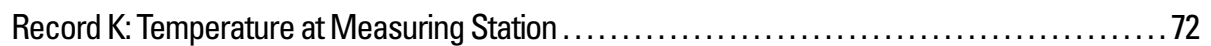

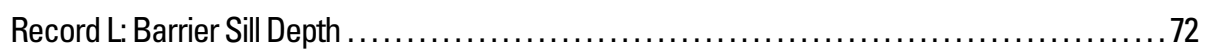

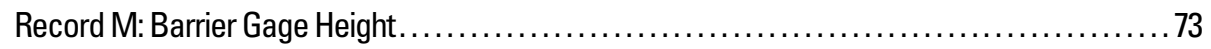

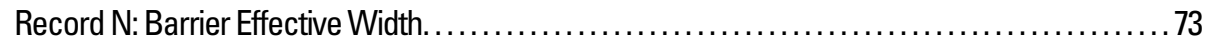




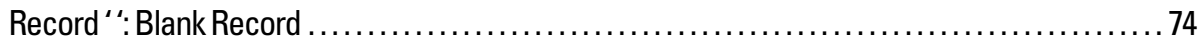

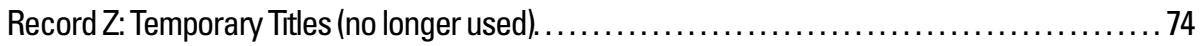

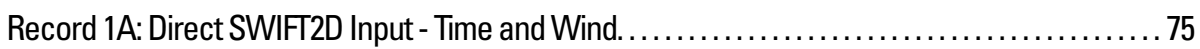

Record 2A: Direct SWIFT2D Input - Water Level and Concentration at Boundary End A . . . . . . 75

Record 3A: Direct SWIFT2D Input - Water Level and Concentration at Boundary End B . . ...... 76

Record 4A: Direct SWIFT2D Input - Concentration at Fourier Tidal Boundary End A........... 76

Record 5A: Direct SWIFT2D Input - Concentration at Fourier Tidal Boundary End B........... 76

Record 6A: Direct SWIFT2D Input - Flowrate and Concentration at Discharge Sources, or

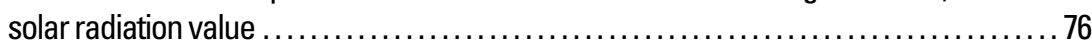

Record 7A: Direct SWIFT2D Input - Sluice Width and Gate Height. .................... 77

Part 4: Records - Space and Time-Varying Wind and Pressure Data . . . . . . . . . . . . . . . . . . . . 78

Part5: Records - Space and Time-Varying Rainfall Data ................................ 779

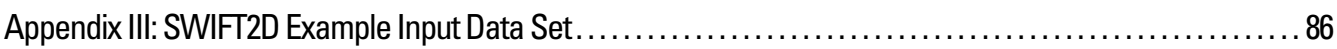

\section{FIGURES}

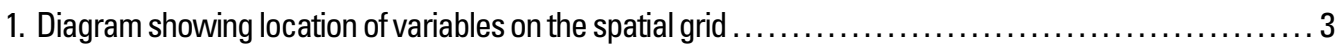

2. Schematic showing flow area with bathymetry points defined at: cell corners and cell centers. ......... 4

\section{TABLES}

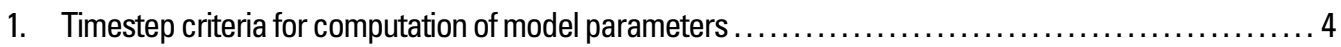

A1. Nonlinear term approximation options in SWIFT2D . .................................. 16 


\title{
A Model for Simulation of Surface-Water Integrated Flow and Iransport in Two Dimensions: User's Guide for Application to Coastal Wetlands
}

\author{
ByEric D. Swain
}

\section{Abstract}

The computation of hydrodynamic flow in two dimensions is implemented in the $\underline{\text { Surface-W}} \underline{\mathbf{W}}$ ater $\underline{\text { Integrated }} \underline{\text { Flow }}$ and Transport in Two-Dimensions (SWIFT2D) model using a numerical code that also includes computation of reactive constituent transport, density variation effects, drying and wetting of periodically inundated areas, and hydraulic structures. The model can be utilized in a variety of settings where velocity and concentration gradients can be assumed to have minimal vertical variations, and the representation of flow in two horizontal dimensions is sufficient. The finite-difference forms of the equations of mass continuity and momentum are solved in two dimensions by the use of a staggered timestep solution solved with an efficient alternating-direction implicit solution. The finite-difference forms of the constituent transport equations can be solved in conjunction with the flow equations. If salt transport is simulated, an equation of state relates the density terms in the momentum equation to salinity.

The traditional formulation of SWIFT2D has been applied to numerous estuaries, bays, and harbors throughout the world. Modifications have been made to expand SWIFT2D for applicability to shallow coastal wetlands. These modifications include the representation of spatially and temporally varying rainfall and evapotranspiration, wind sheltering owing to effects of emergent vegetation, and changes in frictional resistance with depth. These modifications expand the versatility of the code's applications to include open freshwater or saltwater conditions along coasts and within embayments and estuaries as well as associated fresh, brackish, and hypersaline wetlands and marshes linked to such water bodies. Inclusion of precipitation and evapotranspiration processes also permits long-term simulations.

\section{Introduction}

A hydrodynamic application is necessary to simulate surface-water flow and transport in a system with transient nonuniform flow conditions. A two-dimensional solution is considered applicable when the system has appreciable variation in the horizontal dimension and the vertical variations in velocity are negligible. The $\underline{\text { Surface-}} \underline{\mathbf{W}}$ ater $\underline{\text { Integrated }} \underline{\mathbf{F}}$ low and $\underline{\text { Trans- }}$ port in Two-Dimensions (SWIFT2D) model solves the hydrodynamic flow equations in two dimensions in conjunction with transport equations accounting for constituents, heat, and salt. All relevant forcing functions are accounted for, including lateral boundaries with specified water levels or discharge rates, effects of wind drag on the water surface, the Coriolis effect, and internal effects of horizontal momentum diffusion.

The SWIFT2D model also has additional features needed to represent important processes in a coastal simulation domain. When sections of a simulated area dry out, the model accounts for the dry cells and simulates the rewetting of cells from adjacent areas. Additionally, hydraulic structures, useful for representing small-scale features are simulated using their relevant flow equations and control elevations.

Most simulations of coastal bays and estuaries can be successfully implemented with the capabilities described above. However, the application of SWIFT2D to coastal wetlands having significant rainfall and evapotranspiration driving functions requires long-term simulation periods along with further capabilities and modifications. In the past, limitations in computational speed have precluded long-term hydrodynamic simulations. The primary cause has been the need for a relatively short timestep in the solution of the hydrodynamic equations, which makes long-term simulations computationally intensive. With recent advancements in computer capabilities, however, these long-term simulations have become practical. The longer the simulation period, the more important it is to provide code modifications to account for evapotranspiration and rainfall. 
A Model for Simulation of Surface-Water Integrated Flow and Transport in Two Dimensions: User's Guide...

These and other enhancements have been made to the SWIFT2D model specifically to facilitate its application to the southern Florida Everglades. The extremely low land-surface gradient of the Everglades wetlands yields shallow flows with very low velocities that are variously affected both by vegetation in the water column and by wind-sheltering effects of emergent vegetation. Enhancements to the SWIFT2D model to better simulate these vegetative impacts to low-velocity shallow flows in the Everglades include a coefficient in the windfriction term to account for water-surface sheltering and variations in the frictional-resistance coefficient to represent the depth-dependent effects of vegetation and small land-surface irregularities that cause increasingly tortuous flow paths with decreasing depth.

This documentation applies to the surface-water simulation features of SWIFT2D version 2.1. An extension of the model (not covered in this report) has been developed to account for the exchange of surface-water flows and solutes with surficial aquifers in the southern Everglades (Langevin and others, 2004). The SWIFT2D model has been coupled to the SEAWAT three-dimensional ground-water flow transport model (Guo and Langevin, 2002). This coupling allows the transfer of water and the transport of salt between the surfaceand ground-water systems through leakage. SEAWAT was developed from the widely used MODFLOW ground-water flow model (McDonald and Harbaugh, 1988) by attaching the MT3DMS solute-transport code (Zheng and Wang, 1998), which accounts for the effects of salinity on density. The effects of salinity on density and flow are thus represented in both the surface and ground water as well as in the head difference driving the leakage. Details on the application of the combined SWIFT2D/SEAWAT model are found in Langevin and others (2004).

The purpose of this report is to describe the formulation, development, and use of the SWIFT2D model with specific capabilities for the simulation of surface-water processes in dynamic coastal wetlands. This report includes the most recent modifications, a detailed description of the input stream, and an example of model application. Details on the finite-difference formulation of the governing equations are provided in appendix I. Specific SWIFT2D model input and modifications for application in southern Florida are described in appendix II. An example input to the SWIFT2D model is presented in appendix III. This report was prepared by the U.S. Geological Survey as part of its Greater Everglades Priority Ecosystems Science Program and the U.S. Geological Survey/National Park Service Critical Ecosystem Studies Initiative.

\section{Past Applications}

The SWIFT2D model code was originally developed by the Rand Corporation (Leendertse, 1970; Leendertse and Gritton, 1971) and has been applied to a wide variety of water bodies. The model was applied to Jamaica Bay, New York (Leendertse, 1972), used to design the Dutch Delta Works (Dronkers and others, 1981; Leendertse and others, 1981), and modified to evaluate mixing in the Dutch Wadden Sea (Ridderinkhof and Zimmerman, 1992). In a report on a model of the Eastern Scheldt Estuary in The Netherlands, Leendertse (1988) evaluated the effects of the advection term on tidal propagation. These experiments illustrated the importance of the timestep length, grid-cell size, roughness estimation, depth measurement accuracy, turbulence closure, and horizontal momentum exchange.

Schaffranek (1986) and Schaffranek and Baltzer (1990) illustrated horizontal density-gradient effects on estuarine flushing and circulation in the upper Potomac Estuary and the effect of bathymetric grid density on model results using the SWIFT2D model. Schaffranek and Baltzer (1988) also demonstrated the utility of the model in analyzing the hydraulic effects of modifications to wetlands in Port Royal Sound, South Carolina, and floodplains in the Pearl River basin in Louisiana.

In other studies, Lee and others $(1989 ; 1994)$ demonstrated how highway crossings and embankments could affect circulation and flow within an estuarine system that consists of narrow channels and extensive tidal flats, which alternately flood and dewater with each tidal cycle. Studies of flow, circulation, and solute transport in the Pamlico (Bales and Robbins, 1995) and Neuse (Robbins and Bales, 1995) River Estuaries in North Carolina included comprehensive field-measurement programs to provide calibration and verification data for the SWIFT2D model applications.

Further studies have shown the effects of dredging and alternative spoil placement options on tidal flow, circulation, and flushing within several estuaries in Florida including Tampa Bay (Goodwin, 1987) and Hillsborough Bay (Goodwin, 1977; 1991). Application of SWIFT2D to Charlotte Harbor (Goodwin, 1996) and the Loxahatchee River (Russell and Goodwin, 1987) provided insight into the response of tidal flow and mixing characteristics to alterations imposed by proposed causeways and bridges.

Substantial code modifications were made for wetland applications, leading to version 1.1 (Swain, 1999). This includes the initial forms of algorithms to represent rainfall and evapotranspiration, and is the predecessor to SWIFT2D version 2.1 discussed in this report.

\section{Acknowledgments}

The SWIFT2D model presented herein is based on the SIMSYS2D code, a system for two-dimensional simulation of hydrodynamics and water quality, originally developed for the U.S. Geological Survey by Dr. Jan J. Leendertse, retired from the Rand Corporation (Leendertse, 1970). R. Steven Regan, formerly of the U.S. Geological Survey, restructured some of the original computer code using modular programming techniques, modified the code to meet Fortran 77 coding conventions, and added the interactive file-designation and execution mechanisms to facilitate adaptability and ease of use of the model on a variety of computer systems. Raymond Schaffranek 
of the U.S. Geological Survey National Research Program has researched and documented the original SWIFT2D code. John Wang of the Rosenstiel School of Marine and Atmospheric Science has checked, verified, and made useful modifications to the most recent version of the code.

\section{SWIFT2D Modifications}

The SWIFT2D model solves finite-difference approximations of the two-dimensional equations of conservation of mass and momentum. All dynamic terms are retained in these equations, thereby avoiding the simplifying assumptions used in kinematic wave or diffusion analogy formulations. Terms are included in the momentum equation to account for the effects of wind forcing, the Coriolis effect, and subscale horizontal momentum exchange. For this application, the flow equations are solved in the two horizontal dimensions, with implicit assumptions that vertical velocity and concentration gradients are negligible.

The transport component of SWIFT2D solves the equations of constituent transport with dispersion in two dimensions. Up to seven constituents can be used simultaneously where growth and decay reactions are represented, and constituents can interact with each other. If salt is a constituent, density effects of varying salinity concentrations are taken into account in the density terms of the momentum equation. This is accomplished with an equation of state, which relates salinity to density.

The governing equations are solved numerically in SWIFT2D. Values of the controlling parameters also are defined as model input to represent the characteristics of the modeled area. SWIFT2D provides a computational framework to implement this solution.

\section{Formulation and Terminology}

The partial differential equations used in the SWIFT2D model that express horizontal mass and momentum as well as constituent conservation are the two-dimensional St. Venant equations with terms for wind forcing, the Coriolis effect, and horizontal momentum diffusion as defined by Schaffranek (2004). In order to solve these nonlinear equations, they are discretized in time and space on a finite-difference grid. The chosen finite-difference spatial increment must be of sufficient resolution to capture the important physical features of the water body being simulated. The finite-difference time increment is determined based on the prototype wave celerity and the chosen space increment.

The treatment of land elevation (above or below the water surface) in SWIFT2D is described here. The vertical distance from a tidally defined zero elevation datum to the bottom of the water column is entered into the model as a positive quantity in the downward direction, as is common convention in defining bathymetry. In an offshore situation, if the zero elevation datum is chosen to correspond to mean water level, this vertical distance equals the mean depth. Leendertse (1987) and Schaffranek (2004) refer to the vertical distance from zero elevation datum to the bottom of the water column as "depth points." However, in situations where the zero elevation datum does not correspond to mean water level, such as for other tidal datums (mean low water) or nontidal datums, the distance from the datum to the bottom of the water column can deviate substantially from mean depth. Areas inland from coasts are typically higher than tidally defined zero elevation datum, and the vertical distance from the zero elevation datum to land surface is negative upward when input to the model.

In this document, the vertical distance from zero elevation datum to land surface (emergent or submergent) is referred to as the "bathymetry point." Bathymetry points are shown in a schematic of the square space-staggered grid utilized in SWIFT2D (fig. 1). The staggering in space essentially involves a half grid-cell offset of certain parameter locations. As evidenced, the computation of stage and constituent concentration occurs at the center of the grid cells, whereas the bathymetry points are input at the grid-cell corners. The $U$ - and $V$-components of velocity are computed at the cell edges.

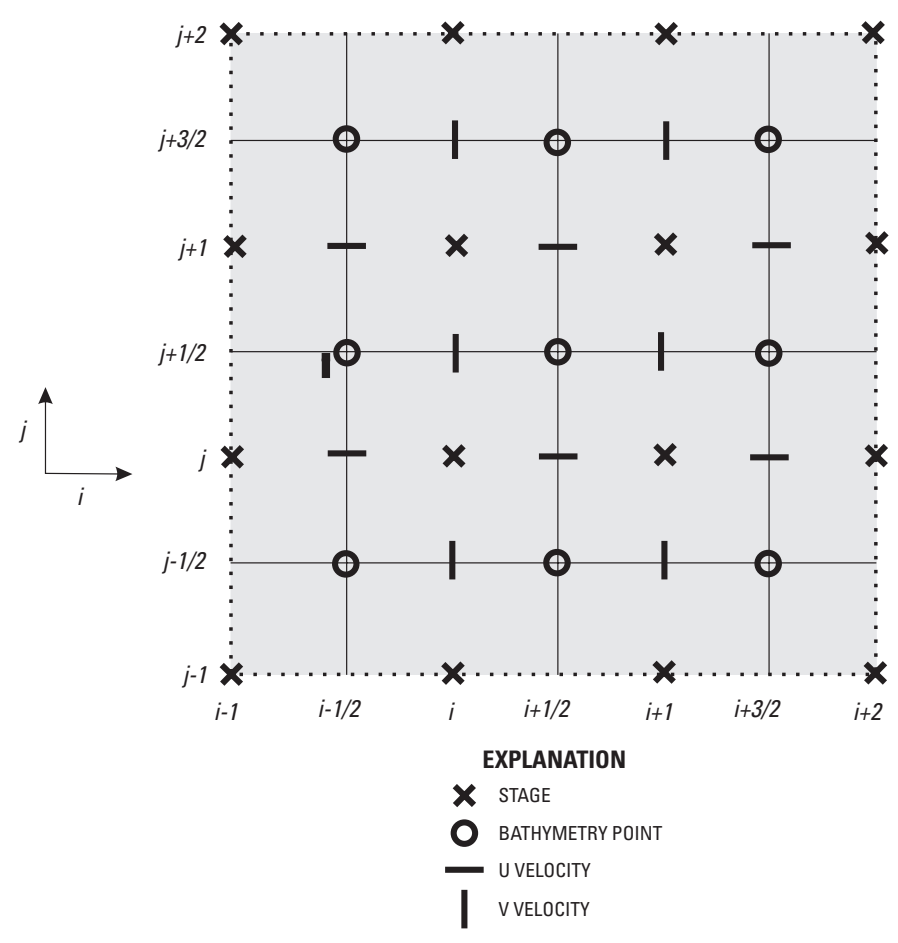

Figure 1. Location of variables on the spatial grid.

The advantage of this scheme comes in the solution of the finite-difference equations. When solving the flow equations between two grid cells, the flow area can be computed based on the bathymetry points at the two adjacent cell corners (fig. 2A). If the bathymetry points were defined at cell centers (fig. 2B), the interpolation to determine the flow area would be less accurate. The staggered-grid scheme (fig. 1) has stage defined at 
A
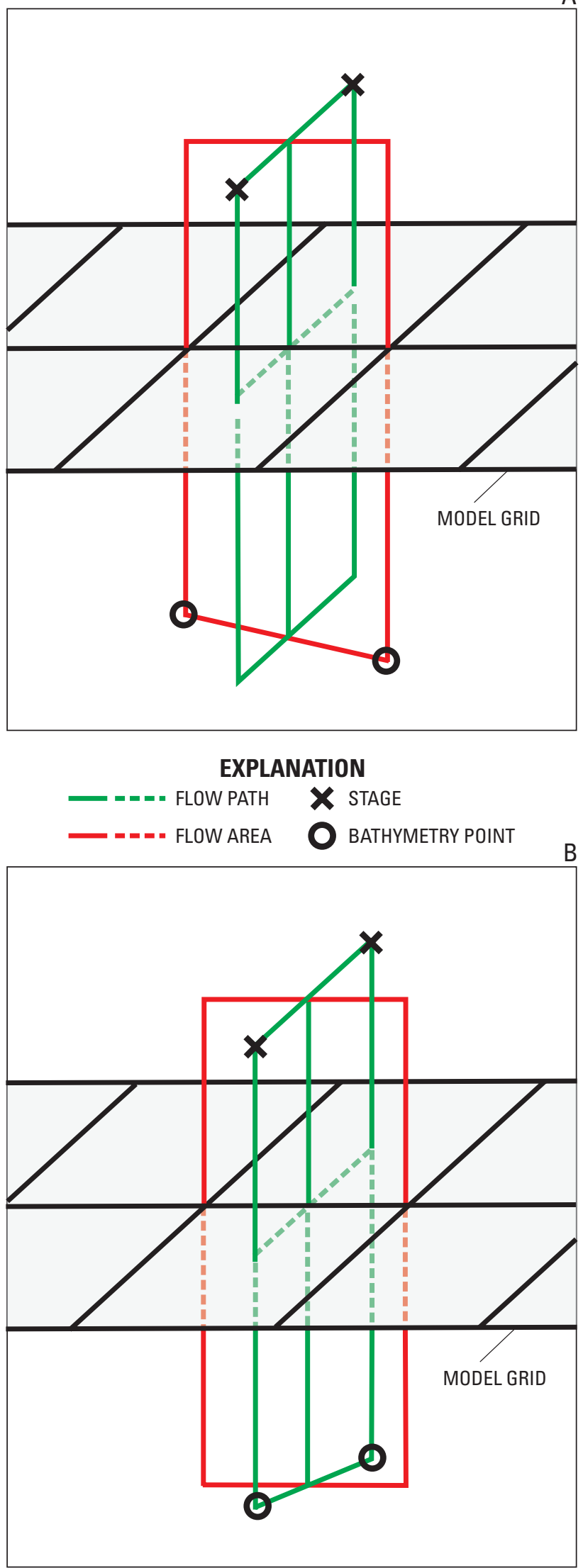

Figure 2. Flow area with bathymetry points defined at cell corners and cell centers. $\mathrm{x}$-locations $(i-1),(i),(i+1) \ldots$ and y-locations $(j-1),(j),(j+1) \ldots$ bathymetry points are then offset to $x$-locations $(i-1 / 2)$, $(i+1 / 2) \ldots$ and $y$-locations $(j-1 / 2),(j+1 / 2) \ldots$ The $U$-velocities are on the column faces at $\mathrm{x}$-locations $(i-1 / 2),(i+1 / 2) \ldots$ and y-locations $(j-1),(j),(j+1) \ldots$. The $V$-velocities are on the row faces at $\mathrm{x}$-locations $(i-1),(i),(i+1) \ldots$ and $y$ - locations $(j-1 / 2)$, $(j+1 / 2) \ldots$

Figure 1 shows how the parameter locations are defined in the conceptualization of the finite-difference equations. It should be noted, however, that when data are placed in an array in the computer code, there are no half indices. This means the bathymetry point at location $(i+1 / 2, j+1 / 2)$ is input and stored at index $(i, j)$. The effect in the model is that, for stage computed at cell $(i, j)$, the lower left corner bathymetry point is stored at index $(i-1, j-1)$. All stage computation cells must have bathymetry points at all four corners, so if the left-most bathymetry points are in column 1 and the lowermost bathymetry points are in row 1, the leftmost stage computational cell must be in column 2 and the lowermost stage computation cell must be in row 2. A defined boundary stage, however, can be defined in row number 1 or column number 1 because it does not require adjacent bathymetry points at all four corners for computation. The same is true for specified velocity boundaries.

Somewhat analogous to the staggered spatial grid is the staggered timestep. The SWIFT2D numerical solution technique is based on an Alternating Direction Implicit method in which the horizontal velocity components $U$ and $V$ are computed at alternating half timesteps. Table 1 indicates the timestep level at which each solution is made. Water levels and constituent concentrations are computed every half timestep, but $U$ - and $V$-velocities are only computed every other half timestep. The manner in which the staggered timestep solution is implemented for the finite-difference forms of the flow and transport equations is discussed in appendix I.

In addition to the solution to the two-dimensional St. Venant equations with wind forcing, the Coriolis effect, and horizontal momentum diffusion, SWIFT2D also has the ability to represent Fourier tide openings, space-varying wind and pressure, drying and flooding of cells, permanently dry cells or dams, and sluices or barriers. These options are described in detail by Schaffranek (2004).

Table 1. Timestep criteria for computation of model parameters

\begin{tabular}{lllll}
\hline \multirow{2}{*}{$\begin{array}{c}\text { Computa- } \\
\text { tion } \\
\text { time }\end{array}$} & \multicolumn{4}{c}{ Time of latest computation of: } \\
\cline { 2 - 5 } & Water level & Concentration & U-velocity & V-velocity \\
\hline $\mathrm{n}$ & $\mathrm{n}$ & $\mathrm{n}$ & $\mathrm{n}-0.5$ & $\mathrm{n}$ \\
$\mathrm{n}+0.5$ & $\mathrm{n}+0.5$ & $\mathrm{n}+0.5$ & $\mathrm{n}+0.5$ & $\mathrm{n}$ \\
$\mathrm{n}+1$ & $\mathrm{n}+1$ & $\mathrm{n}+1$ & $\mathrm{n}+0.5$ & $\mathrm{n}+1$ \\
$\mathrm{n}+1.5$ & $\mathrm{n}+1.5$ & $\mathrm{n}+1.5$ & $\mathrm{n}+1.5$ & $\mathrm{n}+1$ \\
\hline
\end{tabular}




\section{Modifications for Coastal Wetland Simulation}

Several enhancements were made to the SWIFT2D model to simulate hydrologic processes in coastal wetlands. The representation of spatially varying rainfall and evapotranspiration was added for long-term low-velocity simulations where these quantities are important. The incorporation of a wind-sheltering coefficient represents the effects of emergent vegetation on the water-surface wind friction. An empirical representation of vertical variations in frictional resistance is included to account for vegetation effects within the water column.

\section{Time-Varying Areal Rainfall}

For wetland applications having substantial rainfall effects, a subroutine was created in SWIFT2D to read in grids of preprocessed rainfall values at the same time interval specified for tidal input (Langevin and others, 2002). The concentration of all constituents in rainfall is assumed to be zero. After the addition of rainfall to a cell, the concentrations of all constituents within the cell are recalculated based on the ratio of added rainfall volume to total cell volume. Rainfall on dry cells is assumed to infiltrate and does not run off to wet cells.

The rainfall values are read in at the interval defined for tidal values (the input value TITIDE). A flag is read in every interval that indicates if nonzero rainfall exists for that interval $(0=$ no rain, $1=$ rain $)$. If there is rain for the interval, then a grid of values is read in by model grid rows. Currently, the rainfall is read in as inches over the time interval TITIDE. The input format for rainfall data is given in appendix II (part 5).

\section{Spatially Detailed Evapotranspiration}

Enhancements were made to SWIFT2D to include evapotranspiration in the simulation and to treat evapotranspiration at the computational grid scale. In the Everglades, evapotranspiration is the primary mechanism for water loss (Duever and others, 1994). Evapotranspiration rates depend on vegetation characteristics (rainfall interception and leaf area), net solar radiation, wind (advection and turbulent transport), relative humidity, and plant-available water capacity, which is a function of rooting depth, soil hydraulic properties, and water depth (Zhang and others, 2000). Research to determine methods for computing evapotranspiration rates from the relevant parameters produced useful relations from Everglades field sites (German, 1999). The formulation developed in this research is considered most applicable to the Everglades coastal wetland environment and is incorporated as a SWIFT2D model modification. The formulation is based on the Priestly-Taylor equation:

$$
\lambda E=\alpha \frac{A \Delta}{\Delta+\gamma},
$$

where $\lambda$ is the latent heat of evaporation of water, $E$ is the evapotranspiration rate in mass flux per time, $\alpha$ is the dimensionless
Priestly-Taylor (P-T) coefficient, $A$ is the available energy, $\Delta$ is the slope of the saturation vapor-pressure curve, and $\gamma$ is the psychrometric constant. If the terms $\lambda$ and $\Delta /(\Delta+\gamma)$ are approximated as constants, the equation expresses evapotranspiration rate $E$ in terms of the P-T coefficient $\alpha$ and the available energy $A$. Another approximation is to express available energy $A$ (the sum of the net radiation, soil heat flux, and change in heat storage) as a function of solar radiation only. Both of these approximations neglect variabilities in the slope of the saturation vapor-pressure curve, net nonzero heat fluxes, and changes in heat storage.

German (2000) found that 95 percent of the variations in latent heat flux, the energy used for evapotranspiration, could be explained through water-level and solar radiation values only. This allows a simplified representation of evapotranspiration based on fewer parameters that are more easily obtained. German (2000) expressed the P-T coefficient $\alpha$ as a function of solar radiation $R$ and water depth $\zeta$ :

$$
\alpha=C_{0}+C_{1} \zeta+C_{2} \zeta^{2}+C_{3} R+C_{4} R^{2},
$$

where $C_{0}, C_{1}, C_{2}, C_{3}$, and $C_{4}$ are empirically derived coefficients. Regionally applicable values for the coefficients were derived through least-squares regression of data from multiple field sites, using depth $\zeta$ in units of feet and solar radiation $R$ in units of watts per square meter. This yields the values for vegetated areas (German, 2000):

$$
\begin{gathered}
C_{\mathrm{o}}=1.1263 \\
C_{1}=0.1156 \\
C_{2}=-2.71 \times 10^{-2} \\
C_{3}=-8.21 \times 10^{-4} \\
C_{4}=-1.07 \times 10^{-7}
\end{gathered}
$$

With this formulation of $\alpha$ and the approximations to equation 1 discussed above, a relation between the evapotranspiration rate and the computed $\alpha$ and $R$ can be developed by linear regression. The best fit equation is (Swain and others, 2004):

$$
E T=-1.32 \times 10^{-5} \alpha R+2.73 \times 10^{-5} R+2.56 \times 10^{-3},
$$

where $E T$ is the evapotranspiration rate in depth per time. Equations 2 and 3 are used to compute evapotranspiration in SWIFT2D. The evapotranspiration volume for each cell is computed during each computational timestep and is removed from the total cell volume. Constituent concentrations in each computational cell are adjusted for change in water volume. The presence of solar-radiation input is defined in appendix II (part 2, record 3), and the solar-radiation time series in appendix II, (part 3, record set 6A).

There are three considerations when calculating evapotranspiration in SWIFT2D following the principles prescribed by German (2000). First, water lost from beneath dry cells through evapotranspiration is not represented in the SWIFT2D model. Second, the evapotranspiration rate is, in reality, a 
function of available energy in the water column. Solar radiation is a convenient surrogate for available energy. Pyranometer measurements are a useful areal indicator of local solar radiation and an estimate of available energy. However, since solar radiation becomes zero at sunset, when substantial heat energy remains in the water, there is a tendency to underestimate evapotranspiration at sunset. Likewise, evapotranspiration is generally overestimated near sunrise when solar radiation is heating the water. In spite of these discrepancies, predicted evapotranspiration volume over a daily cycle generally is reasonable, being on the order of 0.3 centimeter (German, 2000). Finally, the evapotranspiration algorithm used in SWIFT2D is based on coefficients developed for the southern Florida Everglades and may not be applicable to other geographical areas and water bodies.

\section{Wind Sheltering}

Originally, SWIFT2D was developed primarily for openwater applications in which a spatially uniform coefficient for wind stress on the surface is representative of the entire model domain. In heavily vegetated wetlands, such as the Everglades, however, emergent vegetation can shelter the water surface from wind conditions (Reid and Whitaker, 1976), effectively reducing wind- stress effects. This reduction of wind stress on the water surface is simulated by using a wind-sheltering coefficient (a simple linear multiplier) in the wind-stress term of the momentum equation. The value of this multiplier can be reasonably represented as spatially uniform in areas with emergent vegetation (Jenter, 1999); the value is 1.0 in open-water areas. Information is limited on values of the wind-sheltering coefficient. Although a value of 0.3 has been used successfully in a wetlands application (Swain and others, 2004), further research is needed to better define these values. The coefficient is applied to the wind term in the solution of the momentum equation in SWIFT2D (see appendix I). Instead of requiring the user to define which portions of the model area have emergent vegetation, a coefficient value of 0.3 is applied to all computational cells having a Manning's coefficient greater than 0.1 , which assumes that an assigned high resistance coefficient indicates the presence of emergent vegetation.

\section{Variations in Frictional Resistance with Depth}

In densely vegetated areas with shallow depths, microtopography and vegetation can cause the effective flow resistance factor for a model cell to vary with the flow depth. When upscaling frictional resistance from point measurements at the field scale to represent resistance of an entire model grid, microtopography has the capability of increasing the effective frictional resistance at lower water depths. The variation in topography creates sinuosity in flow, increasing the flow resistance experienced at shallow depths. Based on this functionality, a useful empirical form has been found to represent the variation of Manning's $n$ with depth (Swain and others, 2004):

$$
n_{\text {eff }}=n_{\text {ref }}\left(d_{r e f} / d\right)^{p}
$$

where $n_{\text {eff }}$ is the effective Manning's $n, n_{\text {ref }}$ is the reference Manning's $n, d_{r e f}$ is the reference water depth, $d$ is water depth, and $p$ is the exponent that represents nonlinear characteristics of the relation.

The parameter $d_{r e f}$ is the water depth at which the reference Manning's $n$ value $n_{r e f}$ is applicable. The values of $d_{r e f}, n_{r e f}$, and $p$ should correspond to known values from experimentation. Numerical experiments in a southern Florida wetland indicated that best results were obtained using $n_{r e f}$ values from laboratory experimentation where $d_{\text {ref }}=0.6$ meter and $p=2$ (Swain and others, 2004). The values of these coefficients must depend on the topographic and vegetation features of the application area.

\section{Computational Cells Adjacent to Flow Barriers}

Hydraulic barriers are included in the SWIFT2D computational grid by replacing the normal flow equations at a grid cell with an equation representing the barrier. Barriers may control flow in either the $\mathrm{x}$ - or $\mathrm{y}$-direction and represent weirs, hydraulic gates, bridge piers, or other features. Each barrier is one grid space long, is located at a water-level grid point, and must be specified as either a $U$ - or $V$-flow control. At a barrier, flow is restricted in some form, and a special computation is made to allow for energy loss at the constriction that results in differences in water levels on either side of the barrier.

Certain restrictions apply to the location and arrangement of barriers. Barrier points should be located at least three grid points apart in the direction of the flow and three grid points away from the computational grid boundary. Barrier points can be side by side, forming a row or column to simulate linear features such as a storm-surge barrier. When computational cells adjacent to barriers are wet, the flow barrier acts as a levee or weir. In the original version of SWIFT2D, computations ceased if a computational cell adjacent to a flow barrier in the direction of flow became dry. The SWIFT2D code was modified to provide the constraint that there was no flow over or through a barrier during times when computational cells on either side of the barrier were dry, thus allowing the simulation to continue. Flow is allowed to enter either cell adjacent to a barrier from other directions, and there is no storage of constituents at the barrier when an adjacent cell is dry.

\section{Other Code Modifications}

Several other minor code modifications were made to the SWIFT2D code for application to coastal wetlands:

- Wind stress is not applied in computational cells adjacent to a water-level open boundary. This modification helps prevent numerical oscillations that can develop at a wide open boundary owing to wind forcing. 
- Print routines were modified so that (1) simulated constituent concentrations at selected locations are printed at the same time interval as water levels and discharges, and (2) simulated water levels and velocities are printed to a different file than the remainder of the simulation output.

- The output unit for computed velocities was given increased resolution to accommodate the extremely low-flow velocities of the Everglades wetlands.

\section{Summary}

The $\underline{\text { Surface-W}}$-Water Integrated $\underline{\text { Flow and }}$ Transport in Two Dimensions (SWIFT2D) model has been documented for use in coastal wetlands. The finite-difference model solves the equations of mass and momentum conservation in two dimensions and solute-transport equations for heat, salt, and constituent fluxes. Modifications to the original hydrodynamic formulation for application to areas with emergent vegetation include areal representation of precipitation and treatment of evapotranspiration processes. The modifications to allow the simulation of flow and transport in wetlands also include wind-sheltering effects and the variation of frictional resistance with water depth.

\section{References Cited}

Arakawa, A., 1966, Computational design of long-term numerical integration for the equations of fluid motion: Part I, Twodimensional incompressible flow: Journal of Computational Physics, v. 1, no. 1, p. 119-143.

Bales, J.D., and Robbins, J.C., 1995, Simulation of hydrodynamics and solute transport in the Pamlico River Estuary, North Carolina: U.S. Geological Survey Open-File Report 94-454, $85 \mathrm{p}$.

Dronkers, J., van Os, A.G., and Leendertse, J.J., 1981, Predictive salinity modeling of the Oosterschelde with hydraulic and mathematical models: Transport models for inland and coastal waters: Proceedings of the Symposium on Predictive Abilities: New York, N.Y., Academic Press, p. 451-482.

Duever, M.J., Meeder, J.F., Meeder, L.C., and McCollom, J.M., 1994, The climate of south Florida and its role in shaping the Everglades ecosystem; in S.M. Davis and J.C. Ogden, eds., Everglades-The ecosystem and its restoration: Delray Beach, Fla., St. Lucie Press, p. 225-248

German, E.R., 1999, Regional evaluation of evapotranspiration in the Everglades: Proceedings of the IAHR Third International Symposium on Ecohydraulics, Salt Lake City, Utah, July 13-16, 1999, 14 p.

German, E.R., 2000, Regional evaluation of evapotranspiration in the Everglades: U.S. Geological Survey Water-Resources Investigations Report 00-4217, 48 p.
Goodwin, C.R., 1977, Circulation patterns for historical, existing, and proposed channel configurations in Hillsborough Bay, Florida (section 1-4): Proceedings of the 24th International Navigation Congress: Permanent International Association of Navigation Congresses, Brussels, Belgium, $13 \mathrm{p}$.

Goodwin, C.R., 1987, Tidal-flow, circulation, and flushing changes caused by dredge and fill in Tampa Bay, Florida: U.S. Geological Survey Water-Supply Paper 2282, 88 p.

Goodwin, C.R., 1991, Tidal-flow, circulation, and flushing changes caused by dredge and fill in Hillsborough Bay, Florida: U.S. Geological Survey Water-Supply Paper 2376, 49 p.

Goodwin, C.R., 1996, Simulation of tidal-flow, circulation, and flushing of the Charlotte Harbor estuarine system, Florida: U.S. Geological Survey Water-Resources Investigations Report 93-4153, 92 p.

Guo, W., and Langevin, C.D., 2002, User's guide to SEAWAT, a computer program for simulation of three-dimensional variable-density ground-water flow: U.S. Geological Survey Techniques of Water-Resources Investigations, book 6 , chap. A7, 77 p.

Jenter, Harry, 1999, Laboratory experiments for evaluating the effects of wind forcing on shallow waters with emergent vegetation; in Coastal Ocean Processes Symposium: A Tribute to William T. Grant: Woods Hole Oceanographic Institution Technical Report, $15 \mathrm{p}$.

Langevin, C.D., Swain, E.D., and Wolfert, M.A., 2002, Numerical simulation of integrated surface-water/groundwater flow and solute transport in the southern Everglades, Florida: Second Federal Interagency Hydrologic Modeling Conference, Las Vegas, Nevada, July 28-August 1, 2002, 12 p.

Langevin, C.D., Swain, E.D., and Wolfert, M.A., 2004, Simulation of integrated surface-water/ground-water flow and salinity for a coastal wetland and adjacent estuary: U.S. Geological Survey Open-File Report 04-1097, 30 p.

Lee, J.K., Schaffranek, R.W., and Baltzer, R.A., 1989, Convergence experiments with a hydrodynamic model of Port Royal Sound, South Carolina: Proceedings of the 1989 ASCE National Hydraulic Engineering Conference, New York, N.Y., p. 434-441.

Lee, J.K., Schaffranek, R.W., and Baltzer, R.A., 1994, Simulating effects of highway embankments on estuarine circulation: ASCE Journal of Waterway, Port, Coastal, and Ocean Engineering, v. 120, no. 2, p. 199-218.

Leendertse, J.J., 1970, A water-quality simulation model for well-mixed estuaries and coastal seas: Volume I, Principles of Computation: Santa Monica, Calif., The Rand Corporation, Report RM-6230-RC, 71 p.

Leendertse, J.J., 1972, A water-quality simulation model for well-mixed estuaries and coastal seas: Volume IV, Jamaica Bay Tidal Flows: New York, The New York City Rand Institute, Report R-1009-NYC, 48 p.

Leendertse, J.J., 1987, Aspects of SIMSYS2D, a system for two-dimensional flow computation: Santa Monica, Calif., The Rand Corporation, Report R-3572-USGS, 80 p. 
Leendertse, J.J., 1988, A summary of experiments with a model of the Eastern Scheldt: Santa Monica, Calif., The Rand Corporation, Report R-3611-NETH, 41 p.

Leendertse, J.J., and Gritton, E.C., 1971, A water-quality simulation model for well-mixed estuaries and coastal seas: Volume II, Computation Procedures: New York, The New York City Rand Institute, Report R-708-NYC, 48 p.

Leendertse, J.J., Langerak, A., and de Ras, M.A.M., 1981, Two-dimensional tidal models for the Delta Works: Transport models for inland and coastal waters: Proceedings of the Symposium on Predictive Abilities: New York, N.Y., Academic Press, p. 408-450.

McDonald, M.G., and Harbaugh, A.W., 1988, A modular threedimensional finite-difference ground-water flow model: U.S. Geological Survey Techniques of Water-Resources Investigations Report, book 6, chap. A1.

Reid, R.O., and Whitaker, R.E., 1976, Wind-driven flow of water influenced by a canopy: ASCE Journal of the Waterways, Harbors, and Coastal Engineering Division, v. 102, no. WW1, p. 61-77.

Ridderinkhof, H., and Zimmerman, J.T.F., 1992, Chaotic stirring in a tidal system: Science, v. 258, p. 1107-1111.

Robbins, J.C., and Bales, J.D., 1995, Simulation of hydrodynamics and solute transport in the Neuse River Estuary, North Carolina: U.S. Geological Survey Open-File Report 94-511, 85 p.

Russell, G.M., and Goodwin, C.R., 1987, Simulation of tidal flow and circulation patterns in the Loxahatchee River Estuary, southeastern Florida: U.S. Geological Survey Water-Resources Investigations Report 87-4201, 32 p.

Schaffranek, R.W., 1986, Hydrodynamic simulation of the upper Potomac Estuary: Proceedings of the Water Forum 86: World Water Issues in Evolution, ASCE, New York, N.Y., v. 2, p. $1572-1581$.

Schaffranek, R.W., 2004, Simulation of Surface-Water Integrated Flow and Transport in Two Dimensions: SWIFT2D User's Manual: U.S. Geological Survey Techniques and Methods, book 6, chap. B-1
Schaffranek, R.W., and Baltzer, R.A., 1988, A simulation technique for modeling flow on floodplains and in coastal wetlands: Proceedings of the 1988 ASCE National Hydraulic Engineering Conference, New York, N.Y., p. 732-739.

Schaffranek, R.W., and Baltzer, R.A., 1990, Horizontal density-gradient effects on simulation of flow and transport in the Potomac estuary: Proceedings of the 1990 ASCE National Hydraulic Engineering Conference, New York, N.Y., p. 1251-1256.

Stelling, G.S., Wiersma, A.K., and Willemse, J.B.T.M., 1986, Practical aspects of accurate tidal computations: ASCE Journal of Hydraulic Engineering, v. 112, no. 9, p. 802-817.

Swain, E. D., 1999, Numerical representation of dynamic flow and transport at the Everglades/Florida Bay interface: Proceedings IAHR Third International Symposium on Ecohydraulics, Salt Lake City, Utah, July 13-16, 1999, 9 p. Swain, E.D., Wolfert, M.A., Bales, J.D., and Goodwin, C.R., 2004, Two-dimensional hydrodynamic simulation of surface-water flow and transport to Florida Bay through the Southern Inland and Coastal Systems (SICS): U.S. Geological Survey Water-Resources Investigations Report 03-4287, $62 \mathrm{p}$.

Vreugdenhil, C.B., 1983, Numerical viscosity in alternatingdirection-implicit schemes for the shallow-water equations: Delft Hydraulics Laboratory, Research Report S 484.

Zhang, L., Dawes, W.R., and Walk, G.R., 2000, The response of mean annual evapotranspiration to vegetation changes at catchment scale: Water Resources Research, v. 37, p. 701708.

Zheng, C., and Wang, P.P., 1998, MT3DMS, a modular threedimensional multispecies transport model for simulation of advection, dispersion, and chemical reactions of contaminants in ground-water systems: Vicksburg, Miss., Waterways Experiment Station, U.S. Army Corps of Engineers. 